4）使用中脆化抑制认対するVの効果は，主として粒 界脃化元素 P.および Mn の粒界への偏析が抑制される ことにある。

\section{参考 文 献}

1) M. Okumura, M. Kumagai, H. Nakamura, K. Kohira ; "Electroslag Welding of Havy $21 / 4 \mathrm{Cr}-1 \mathrm{Mo}$ Steel", Wdg. Jnl. Res. Suppl., Vol. 55 (1970), No. 12, 389s 399s

2) 奥村, 今井，中村：“栖厚 $21 / 4 \mathrm{Cr}-1 \mathrm{Mo}$ 鋼のェレクトロスラダ浚接 金属の特性” 在力技術, vol. 16 (1978), No. 1, 16 24
3) P. Bastien, H. Varon, C. Roques; "Aciers speciaux résistant à la corrosion sous tension par I'hydrogéne sulfurá”, Rev. Met. , Vol. 55 (1958), 301 317

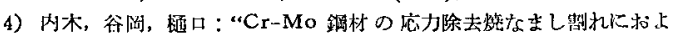

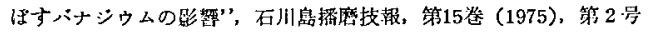
202 208

5) R. Viswanathan, A. Joshi; “Effect of Microstructure on the Temper Embrittlement of Cr-Mo-V Steels", Met. Trans., Vol. 6A (1975), December, 2289 2297

6）奥村，百合䦗，今年，中村：“ $2 \frac{1}{4} \mathrm{Cr}-1 \mathrm{Mo}$ 鎙エレクトロスラグ浴

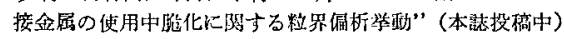

\title{
$21 \frac{1}{4} \mathrm{Cr}-1 \mathrm{Mo}$ 鋼エレクトロスラグ溶接金属の 使用中脆化に関する粒界偏析挙動*
}

\author{
奥村 諴**百合岡信孝**今井 兼敬**中村 治方*** \\ Grain Boundary Segregation of Solute Elements in \\ Embrittled 21/4 Cr-1Mo Electroslag Weld Metals*
}

by Makoto Okumura**, Nobutaka Yurioka**, Kaneyuki Imai** and Harumasa Nakamura***

Thermal embrittlement of $21 / 4 \mathrm{Cr}-1 \mathrm{Mo}$ electroslag weld metals in high temperature operation was studied in this report, with particular emphasis on grain boundary segregation of solute elements proved by Auger spectrum analysis.

The main conclusions obtained in the study were as follows:

(1) The embrittlement were mainly caused by grain boundary segregation of phosphorus.

(2) Silicon and manganese acted as promote the segregation of phosphorus, and also manganese itself did embrittled grain boundaries by segregation like copper and some carbides.

(3) Small precipitates on grain boundaries, which were supposed chromium and/or molybdenum carbides, gave favorable site for segregation of phosphorus.

(4) Sulphur in weld metals occupied grain boundaries after welding and postweld heat treatment, being

in contrast with no occupation in base metals. This might be main reason why weld metals were much less tough, compared with base metals when fracture occurred in grain boundaries such as thermal embrittlement.

(5) Segregation of phosphorus and other solute elements increased with holding time in isothermal treatment and reached to a saturated value. Degree of segregation was larger for phosphorus than for carbon, chromium and molybdenum.

(6) Progress of segregation of solute elements was more rapid than that of embrittling.

(7) Correlation of embrittlement between step cooling and isothermal treatment was not definite and changed depending on chemistry and thermal history of weld metals.

(8) C-curves of isothermal embrittlement of $21 / 4 \mathrm{Cr}-1 \mathrm{Mo}$ welds had an intermediate mode between that of Ni-Cr steel by Jaffe and that of Cr steel by Vidal.

\footnotetext{
*原稿受付 昭和58年 2 月28日（全国大会馀文発表講演）

“正只新日本制鉄(株), Member, Nippon Steel Corp.

***.正貝 全属材料技街研究所 Member, National Research Institute for metals

(元新日本製鉄（朱)) (formerly Nippon Steel

Corp.)
}

\section{1. 緒言}

石油精製プラントを始めとする各種化工機分野では， 圧力容器が高温高圧の下で長時間操業されるととによ 
り，母材および溶揬部の靯性劣化，とくに溶接金属の熯 性が少化する現象が認められ使用中脆化として注目され ている.

この代表的な例として, 重油直接脱硫王力容器に用い ている極厚 $2 \frac{1}{4} \mathrm{Cr}-1$ Mo 銅 (ASTM·A387Gr. 22 銅)の 場合が誉げられる。

従来までの研妴絬果によると，てれは葛温焼むどし脆 性（約 $375^{\circ} \mathrm{C} \sim 575^{\circ} \mathrm{C}$ の温度籁目で長時間加熱又はとの温 度笔間を徐冷させると脆化する）が主因となって生じて いるあのと考えられている。しかし，との烧むどし脆性 そのあのが現象的に未だ明確にされていない点ああり， 脃化機構汇関する解釈汇屯諸説があり，統一見解が得ら れていない.

現実の問題として，現在市眅されている鋼板について は，稼動前に十分高鞄性であり，稼動中の鞄性劣化を見込 んでも設計寿命内は十分化安全であると言える。溶接金 属については，母材に比べて，ミクロ偏析，不純物の混 入, 組織等において使用中脆化を生じやすく，正力容器の 稼動中の脆化はとくに溶揬金属任注目する必要がある。

本報では，溶接金属の使用中脆化について，粒界编析 挙動の钼点から検討した絬果を報告する。

\section{2. 実 験 方 法}

\section{1 供試材料}

Table 1 亿示す供試溶按金属は, 試作ワイヤと市敗の 中酸化マンガン系フラックスを用いてエレクトロスラグ 溶揬により作㱔した。

Table 1 Chemical compositions of weld metals tested

\begin{tabular}{|c|c|c|c|c|c|c|c|c|c|c|c|}
\hline \multirow{2}{*}{ Symbol } & \multicolumn{10}{|c|}{ chemical compositions (wt. \%) } & \multirow{2}{*}{ remarks } \\
\hline & c & Si & Mn & $P$ & $s$ & $\mathrm{Cu}$ & $\mathrm{Cr}$ & Mo & $v$ & $\bar{x}_{\mathrm{ppm}}$ & \\
\hline A & 0.112 & 0.26 & 0.84 & 0.007 & 0.005 & 0.06 & 2.43 & 0.96 & 0.027 & 10.9 & \multirow{6}{*}{$\begin{array}{l}\text { effects of } \\
\mathrm{Si}, \mathrm{Mn} \text { and } \mathrm{Cu}\end{array}$} \\
\hline B & 0.118 & 0.26 & 1.15 & 0.008 & 0.007 & 0.08 & 2.42 & 1.05 & 0.015 & 10.3 & \\
\hline$c$ & 0.112 & 0.26 & 0.63 & 0.009 & 0.012 & 0.09 & 2.35 & 1.04 & 0.018 & 12.7 & \\
\hline D & 0.118 & 0.27 & 0.73 & 0.006 & 0.008 & 0.18 & 2.39 & 1.04 & 0.013 & 8.0 & \\
\hline$E$ & 0.108 & 0.11 & 0.77 & 0.006 & 0.006 & 0.07 & 2.28 & 1.03 & 0.013 & 10.2 & \\
\hline$F$ & 0.114 & 0.36 & 0.79 & 0.007 & 0.008 & 0.10 & $2.4 i$ & 0.97 & 0.010 & 9.2 & \\
\hline ES & 0.100 & 0.25 & 0.82 & 0.006 & 0.007 & 0.08 & 2.35 & 1.05 & 0.027 & 9.3 & $\begin{array}{l}\text { squi embrittlement } \\
\text { curve }\end{array}$ \\
\hline - & $\begin{array}{l}0.114 \\
-0.125 \\
0.25\end{array}$ & $\underset{\sim 0.17}{0.08}$ & $\begin{array}{l}0.72 \\
-0.80\end{array}$ & $\mid 0.007$ & 0.008 & - & $\begin{array}{ll}1.2 \\
-3.1 \\
\end{array}$ & $\begin{array}{c}0.88 \\
\sim 1.08 \\
\end{array}$ & $\underset{\sim 0.02}{0.01}$ & & $\begin{array}{l}\text { effects of } \mathrm{Cr} \text { and } \\
\text { Mo }\end{array}$ \\
\hline - & $\begin{array}{l}0.109 \\
-0.114 \\
\end{array}$ & $\begin{array}{l}0.29 \\
-0.34 \\
-0.34 \\
\end{array}$ & {$\left[\begin{array}{l}0.71 \\
\sim 0.74\end{array}\right.$} & {$\left[\begin{array}{ll}0.006 \\
-0.007\end{array}\right]$} & 0.008 & - & $\begin{array}{ll}2.32 \\
-2,38\end{array}$ & $\begin{array}{l}1.01 \\
-1.04 \\
\end{array}$ & - & $\begin{array}{r}<0.005 \\
\sim 0.034 \\
\sim\end{array}$ & effects of $\mathrm{Ti}$ \\
\hline
\end{tabular}

溶接条件は，通常，実機製作の際用いられる標準的な 条件であり，同様に，熱処理条件む実機製作過程で想定 されるごく一般的な熱処理履原に近似させ，930 $\mathrm{C} \times 4 \mathrm{~h}$ 焼入れ（平均冷速 $10 \sim 15{ }^{\circ} \mathrm{C} / \mathrm{min}$ ), $665^{\circ} \mathrm{C} \times 7 \mathrm{~h}$ 焼 屯ど し (空冷), さらに長時間の SR (応力除去なまし) 処理 $695^{\circ} \mathrm{C} \times 22 \mathrm{~h}$ (T.P. $=20.7$, 平均冷速 $25^{\circ} \mathrm{C} / \mathrm{h}$ ) を施した1).

\section{2 使用中脆化評価試験}

使用中脆化を再現させる手法としては，別報2)之同様，
加速脃化熱処理 (G. E. Step Colling)を行うと同時に, 定温長時間保持による脆化処理も併用した。

\section{3 オージェ電子分析}

粒界偏析挙動の解析に用いた装置は，乙れ委別就之同 様 ${ }^{2)}$ ，走查型オージェ電子份析装置 (SAM) であり，走 查㤠電顕機檋および試片破断機權を有している。試料を 装置内 (真空)で破断後，ただちに粒界破面を選びだし 破面の極表而におりる各元素濃度の测定を行なった。

測定条件は，加速電圧 $2 \mathrm{keV}$ (ただし， $\mathrm{Si} ， \mathrm{Cu}$ の测定 等は，测定感度をあげるため，5 keV で行なっている)， 試料電流 $2 \times 10^{-6} \mathrm{~A}, 1$ 次電子ビーム径約 $10 \mu$ で行ない, データ解析には，测定データを統一するため加速電圧 2 $\mathrm{keV}$ 相当に換算した数值を用いた。

なお，䊚界破面上に析出する微少粒子の表面偏析につ いては，ビーム径を約 $0.3 \mu$ 亿絞って测定した.

\section{3. 実験結果および考察}

\section{1 成分の影響}

脆化住対する各元菜の影響に関しては，従来より多く の何笲埌告があり，腃化不純物元䕀 (P, Sb, Sn, As 等) と，そ机と交互作用を有する合金元素の存在が俥裂であ ると一般に指摘されている。

Table 2 は，腕化挙動の異なる代表的な試料を選ん でオージェ電子分析测定を行なった結果である。偏析 测定値の测定点（粒界ファセット）钟のバラッキは極め て大きい.

T. Table 2 Results of Auger spectrum analysis of embrittled specimens

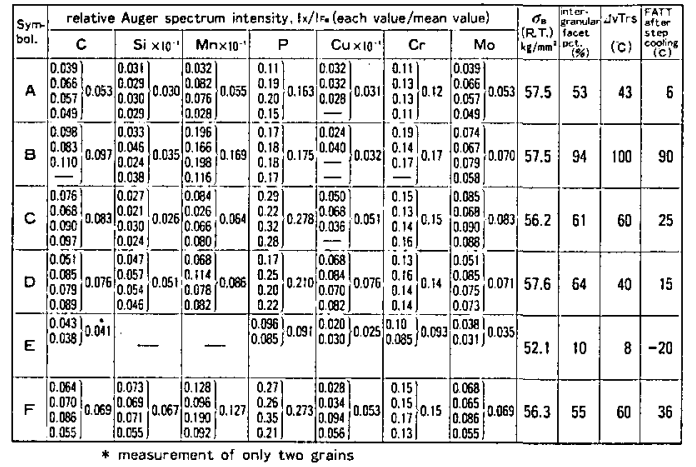

この点は，中村3）等も焼をよ゙し椸化した陚料の精界偏 析を測定し，ファセット整にその值が大きく变動する点 を認めている. 又，McMahon' ${ }^{4}$ は統計的に，乙れ等测 定值の変動がワイブル分布を星するとし，脃化に関与す る粒界ファセットでの最大偏析值を確率諭的に推筀する ことを試みている．但し，著者等の測定では，测定時間 
の制限註)から， 1 試料につき測定点は $2 \sim 4$ 点に限定さ れたので，以下の検傠では，測定值の平均之变動巾で示 すことにした。

1) りん

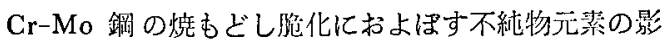
篦に関しては，谜来より多くの報告がなされており， Bruscato $^{5)}$ の脆化指数をはじめ程々の指满が提示されて

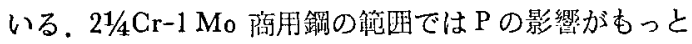
草しいと一般に認められている。

本実験に网いた試料は，いずれも $\mathrm{P}$ が $60 \sim 80 \mathrm{ppm}$ 之

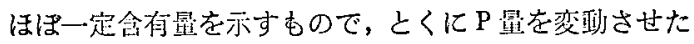
試料でない，ただし，Fig. 1 に示すように，Pの粒界倐 析量 $\left(I_{p} / I_{\mathrm{Fe}}\right)$ と脆化処理後の破面遷移温度との閦係を みると，高 $\mathrm{Mn}$ 系試料を除さ，良好な相関が得られてお り，エレクトロスラグ溶接金属に扔いても，Pの粒界倔 析が使用中脆化の一要因であることがわかる。

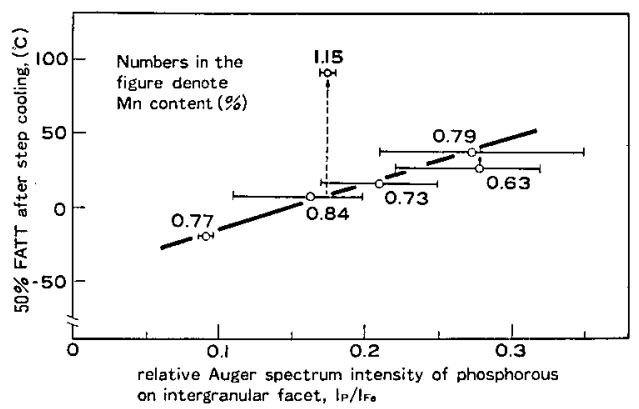

Fig. 1 Relationship between integranular concentration of phosphorus and FATT of 2 $1 / 4 \mathrm{Cr}-1 \mathrm{Mo}$ electroslag weld metals after step cooling

2) けい榇およびマンガン

Fig. 2 は, 粒界の偏析量のみに着目し，P の粒界偏析 量と $\mathrm{Mn}$ および Si の粆界偏析量との関係を整理したも のである．低 $\mathrm{Mn}$ ，高 $\mathrm{Mn}$ 系を别にすると，粒界への $\mathrm{Mn}$, Si の偏析が大きいあのは, 粒界へのP D偏析む大 きいという傾向がみられる，すなわち，脆化の主要因の 一つである $\mathrm{P}$ の粒界偏析量を制御する因子として, $\mathrm{Mn}$, Si の粒界偏析が考えられるわけで,脆化に刘する $\mathrm{Mn}$, Si の間接的役制加推定される.

一方，粒界编析量之供試溶接金属試片中の地の含有量 との関係を調べてみる, Si の場合粒界偏析量は供陚片 の地の含有量に依存しているのに対し，Mn は, 必ずし 古試片中の地の含有量に依存せず，むしろ，FIg. 2 に示 すように，Si の粒界偏析量と良く対応しており，上述の

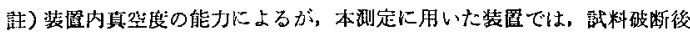

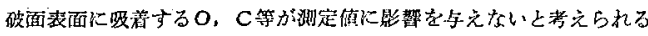
㭙間怕莴々 2 時閐程度である.

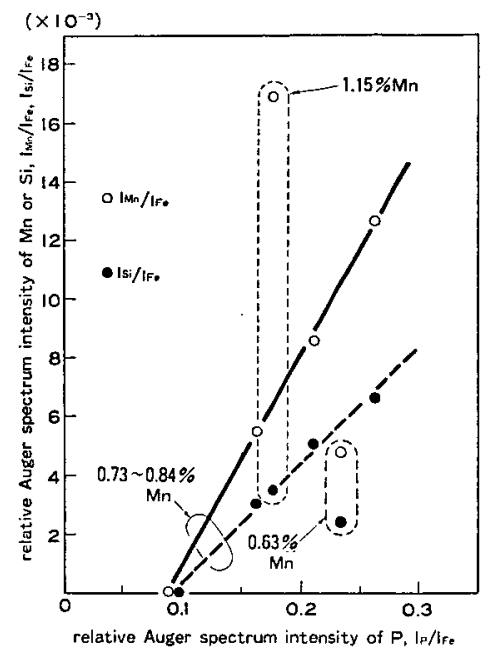

Fig. 2 Relationship between intergranular concentration of $\mathrm{P}$ and of $\mathrm{Mn}$ or $\mathrm{Si}$

間接的役割を担う成分としては，Mn は従であると考え るのが妥当と思われる。

なお，Fig. 1 および 2 を比較すると，忘 Mn 試料の データにみるように，P の粒界偏析显は小さいにむかか わらず，Mnの粒界编析量および脆化量が，極端に大き い点が注目される。すなわち，Mn 量が比較的多い場合 には，上述の P の精界偏析を促進させるという間接的役 割 (Si が主, Mn は従) とは別飞，粒界に偏析する $\mathrm{Mn}$ それ自体が脆化に直接寄与していると推定される。また， Si の粒界偏析に関しても，䊀界に偏析した Si が硬化相 を形成し，直接，胞化を生じさせると考えることもでき るが, 著者等は, Si の粒界编析の役割は，上述の上うに， 主要脕化元菜であるP の粒界偏析を增大させるというあ くまで間接的役割であるうと考えている.

3）炭素,クロムおよびモリブデン

Fig. 3 は，Cの粒界偏析量と脆化処理後の破面遷移温

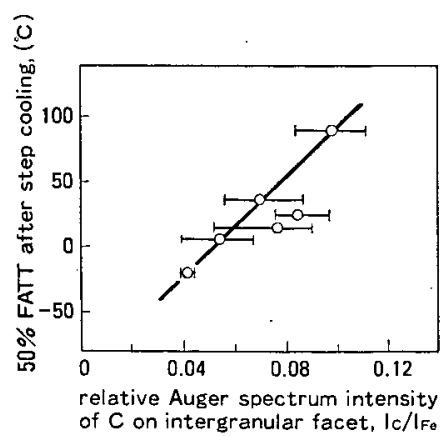

Fig. 3 Relationship between intergranular concentration of $\mathrm{C}$ and FATT of weld metals after step cooling 
度との関係を示したものであるが，非常に良い相関が得 られている。

Fig. 4 は，炭化物形成元蒜である Cr, Mo と C との 相互作用之云った細点で整理したものである．図から明 らかなように雨者の間に明瞙な直線関係が得られてお り，粒界に岸化物が析出していると考えられる。

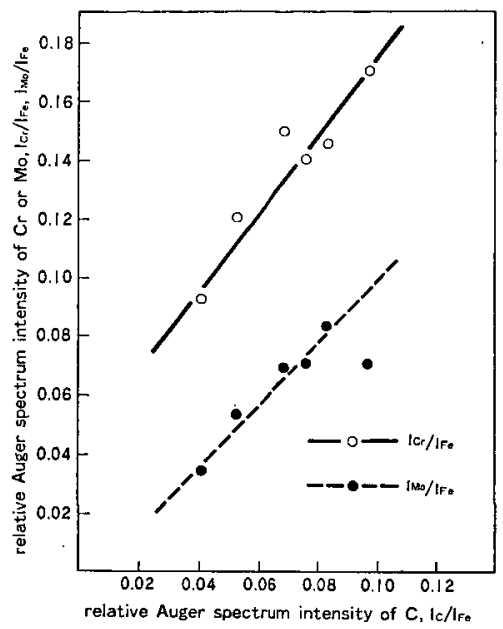

Fig. 4 Intergranular concentration of $\mathrm{G}$ versus that of $\mathrm{Cr}$ or Mo

從って，Fig. 3 および 4 の結果を合せて考えるよ，脃 化現象之粒界における炭化物析出挙動之の関速力示唆さ れる，すなわち，粒界に析出した炭化物は，直接又は閆 接的に脆化要因の一つとして作用していると思われる.

Fig. 5 は，Cr 量变化と使用中脆化量との関係を示す. 低 $\mathrm{Si}$ 化の效果により，1\% Cr から $2.5 \% \mathrm{Cr}$ 量まで は脆化の程度は非常に小さいが， $3 \% \mathrm{Cr}$ 量になると低 $\mathrm{Si}$ 系 $(0.15 \%)$ であ大きな脆化を示しており, $\mathrm{Cr}$ 量が 多い領域では，笵化感受性が増大すると云える.

一方，Mo については，鋼種規格の成分籁围内（1\%

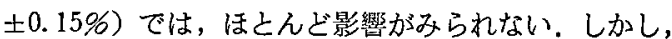
笵围を越えて Mo 量を下げると著しく脆化が軽減され， 從来の報告62 と同㥞に，エレクトロスラグ溶接 金属で 屯，0.5 0.7\%程度が最す脃化感受性を低くするという ことが，著者らの別の実験で確認されている。

4) 銅

Cu については，鋼材又は溶接ワイヤーメッキからの

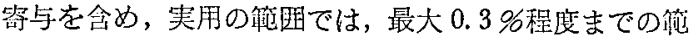
围でその影響老榆澍すればよいと考えられる。

Fig. 6 は， Cu の粒界偏析と脆化量の関速について整 理した結果を示す。粒界への Cu の偏析量は，溶接金属 中に含まれる $\mathrm{Cu}$ 量の増加之共に，直線的に増大してお り，Cu は P のような脆化不純物元素之同様，粒界エネ

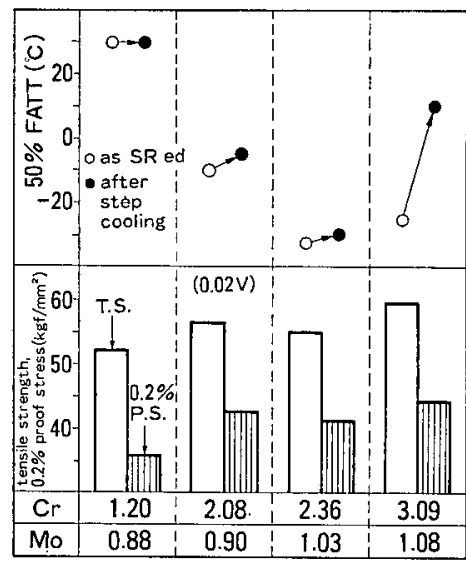

low Si type:0.12C-0.15Si-0.75Mn-0.01V

Fig. 5 Effects of $\mathrm{Cr}$ on thermal embrittlement of weld metals (low Si type; $0.12 \mathrm{C}-0.15 \mathrm{Si}$ $0.75 \mathrm{Mn}-0.01 \mathrm{~V}$ )

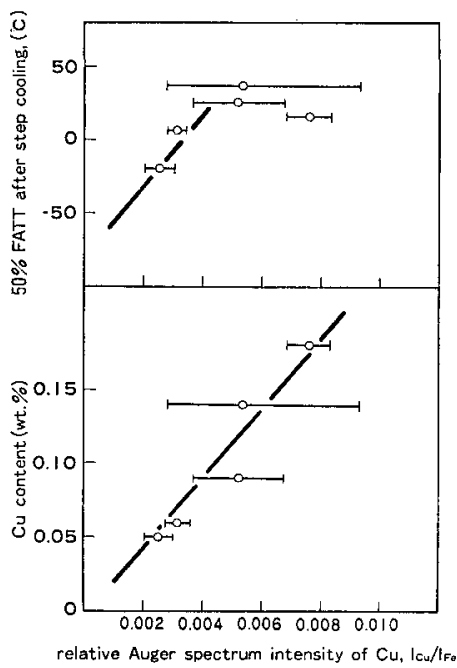

Fig. 6 Copper content, its grain boundary segregation and FATT of weld metals

ルギーを低下させ，ひいては脆化を生じさせると考えら れる。

5) 微量源加元素 (バナジゥム,ニオブおよびチタン) 以上の主要成分の他に，溶揬金属の高温強度確保のた めに, V, Nb， $\mathrm{Ti}$ といった析出硬化型元秦の微量添加 が行なわれるととが多い、V は，別報2で述へたよう に，溶接金属に適正量添加することにより，高強度・高 靶性を保つ之同時に脆化をほとんど抑えるととが可能で ある. しかし， Nb については，0.01〜0.03\%の微量添 加化上り，脆化処理前に鞄性の低下が大きく，強度上鼠 の利点を活用しえない成分であるととがわかっているり 一方，Tiは脆化を轻減するという報告7)があるが; Fig. 
7 に示すように，21/4 Cr-1 Mo 鋼エレクトロスラグ溶接 金属では，ての点若干異なる結果が得られている。図に 示すごとく, 極く微量の. $\mathrm{Ti}$ 添扣域に扔いて, 鞄性の改 㙓がみられるが，使用中脆化は軽減されない，Ti をさ らに添加していくと，鿒性が低下し無源加の埸合と比較 しさらに悪くなる，顕微鏡組織観察によると，溶接金属 中の $\mathrm{Ti}$ 量が0.02\%以上に増量した時点で，ポリゴナル フェライト相が観察され破面逻移温度上昇（勒性低下） の原因となっており，てれが見かけ上の脆化感受性を低 減させている.

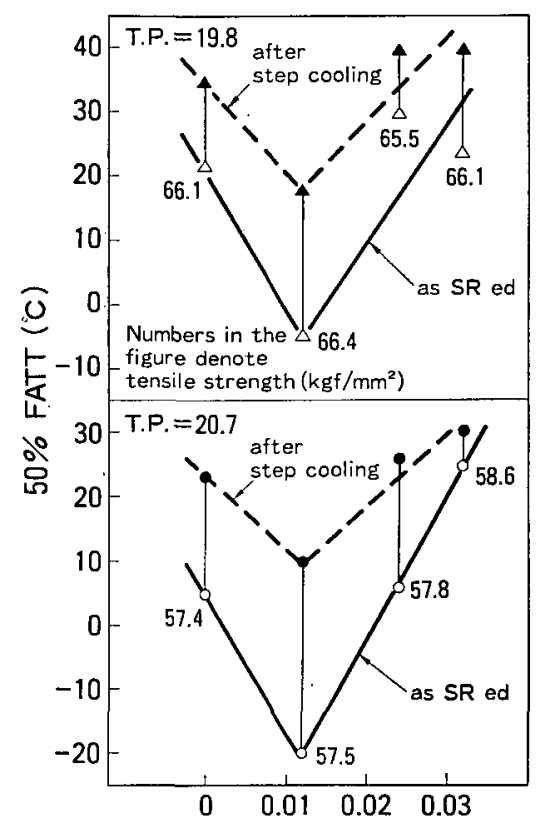

Ti content in weld metals (\%)

Fig. 7 Effects of $\mathrm{Ti}$ on thermal embrittlement of weld metals at two levels of heat treatment $(0.11 \mathrm{C}-0.3 \mathrm{Si}-0.75 \mathrm{Mn}-2.35 \mathrm{Cr}-$ $1.05 \mathrm{Mo}-0.01 \mathrm{~V})$

\section{2 温度 - 時間传存性}

\section{1) 脆化 $\mathrm{C}$ 曲線}

21/4 Cr-1 Mo 成分系で脆化現象が認められている重油 直接脱硫圧力容器の稼動温度は, 王力容器の構造および プロセス等により違いがみられるようであるが，現状で は $400{ }^{\circ} \mathrm{C}$ 前後が一般的である. 一方古くから知られてい る低合金鋼焼もどし脆化現象の脆化温度域は，約 $375^{\circ} \mathrm{C}$ 〜 575 足 とかなり広域にわたっており，その温度一時間 依存性汇関する実験例として L. D. Jaffe 等による $\mathrm{Ni}$ - $\mathrm{Cr}$ 鋼の脆化 $\mathrm{C}$ 曲線吕良く知られている8).

現在，乙の烧むどし脆化特性を実験室的に評価する加 速脆化訊験として用いられている各租 step colling 法
あ，てれら実験報告に基づいて設定され，その後改良さ れてきたあのである. 従って, step cooling 法による結 果偟よって実際の使用中脆化現象（定温長洔間保持の脆 化）を評洒するということはあくまです便宜上の手段で あって，雨者の相関を朋らかにしておくことが望まれ る.

Fig. 8 は, エレクトロスラグ溶接金属の基本成分系に ついて脆化温度域にある 5 段階の温度設定で最高 5,000 〜10,000特間保持して等胎化曲線を作成したあのであ る.

Jaffe の実験例は， Ni-Cr 鋼であり，成分呫よび熱処 理履楚等異なっているので, 等脳化曲線 ( $\mathrm{C}$ 曲線) の舅 (nose) の位置は当然違っているが，nose が右下りの傾 向を呈する等，類似点むみられる。G. Vida ${ }^{99}$ は， $\mathrm{Cr}$ 鋼 を用いて同様の垁験例を郝告しているが, 著者らの結果 は, Vidal の等脆化曲線と屯類似点がみられ，雨者 (Jaffe および Vidal の等脆化曲線) の中間的形状を呈して いると言える。なお，図内に太実線として step occling による脆化量に相当する仮想の等脆化曲線を示してある が, 重汕直接脱硫プロセスの稼動温度の上限 $450{ }^{\circ} \mathrm{C}$ の線 上でみると, 基本成分系では, step cooling による脆化 度は $450^{\circ} \mathrm{C}$, 約 $2,000 \mathrm{~h}$ 保持の船化度に対応している。 ただし，乙の結果は化学組成その他因子を固定した場合 で，化学組成および熟処理履歷等の因子が変ることによ り脆化感受经が晎なると，乙の相関はかなり变動し明膫 ではない。

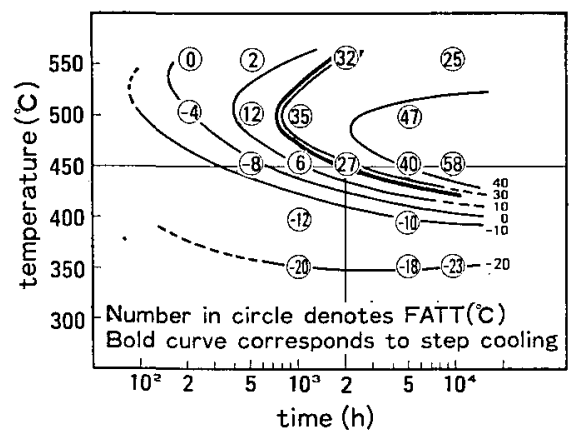

Fig. 8 Temperature-time curves in thermal embrittlement of $21 / 4 \mathrm{Cr}-1 \mathrm{Mo}$ electroslag weld metals

Fig. 9 は，その状沉を示した一例である。Si Si高目に し, 脆化感受性を增大させると, $450^{\circ} \mathrm{C} \times 2,000 \mathrm{~h}$ 処理の 万が, step cooling より荷酷になるが，Si 低目にし， 脆化感受性を抑制すると, むしろ step cooling の方が苛 酷になる。乙の相関は, 試料の履歴 (とくに熱処理履 歴）によっても㖕なり，大型継手形式で試料を作製した 


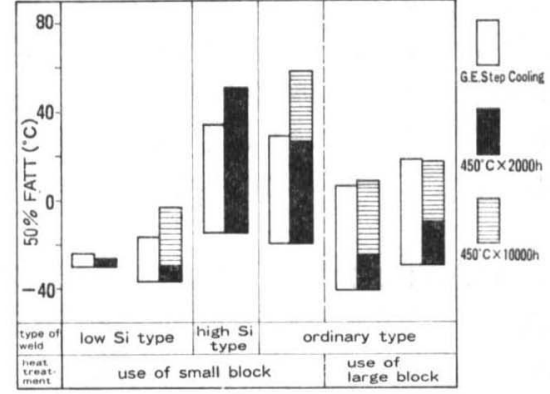

Fig. 9 Relationship between an isothermal and an accelerated embrittling treatment

場合は，一般的に step cooling は定温保持より屯苛酷な 結果を与えるととがわかる。

2）粒界偏析（オージェ電子分析）

使用中脆化に関する温度 ·時間低存性を粒界偏析挙動 の锥点から検討するため脆化処理前後にみられる粒界破 面に対しオージェ電子分析測定を行なった. 測定結果に よると, 予想通り $\mathrm{P}, \mathrm{Cr}, \mathrm{Mo}$ 等のオージェピークは, 脆化処理時間が長い程大きくなっており, 粒界偏析と脆 化との定性的対応が観察される.

Fig. 10 は, 主要脆化元素である P の粒界偏析量と破 面遷移温度の経時変化を比較して示したものである. 脆 化量の増加（破面遷移温度の上昇）之粒界偏析 $\mathrm{P}$ 量の増 加はほぽ同じ挙動を呈しているようにみえるが, 詳細に みると, 脆化の進行に先立って, 粒界偏析が早く進行し ており, とくに $500{ }^{\circ} \mathrm{C}$ 保持においてその傾向が著しい. この点は, P の粒界偏析の他に, 3.1 項で述へたような 肘化の副次的要因が介在していることを示唆している.

Fig. 11 は, C, Cr, Mo 等の炭化物形成元素について

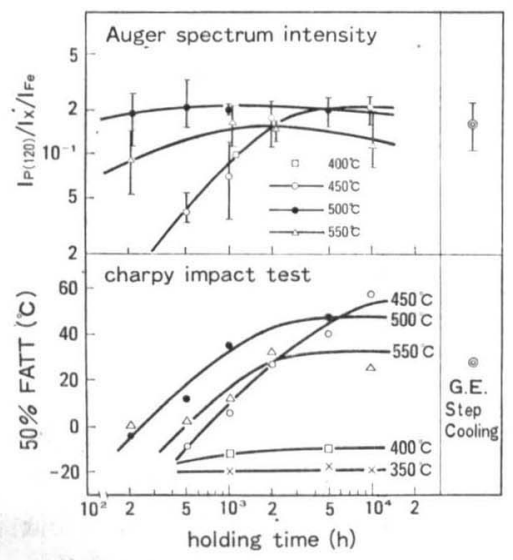

Fig. 10 Intergranular segregation behavior of $\mathrm{P}$ and change of toughness at several temperature

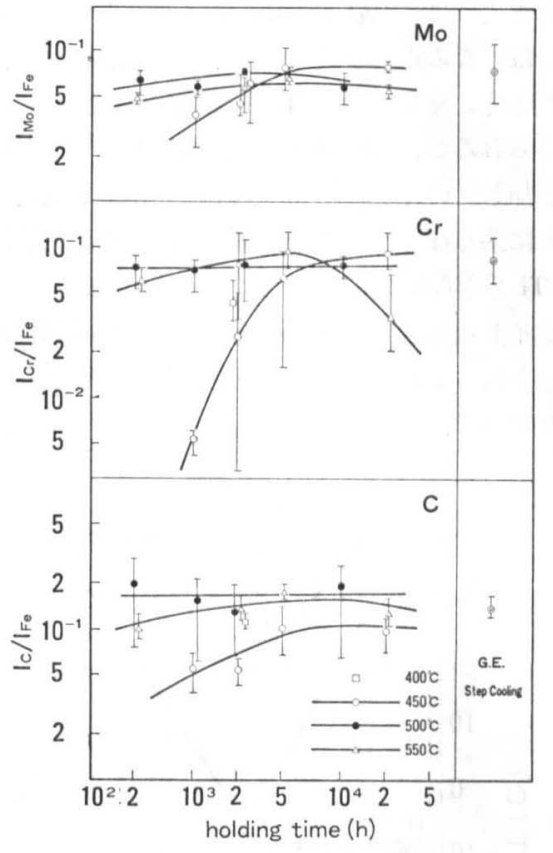

Fig. 11 Intergranular segregation behavior of C, $\mathrm{Cr}$ and $\mathrm{Mo}$ at several temperature

粒界偏析量の経時変化を比較して示したあのである．P に比べると変化量は小さいが, 定性的に脆化量の変化と 対応しており, 又脆化の進行に比べ, 偏析の進行の方が 早いといった傾向も同様に観察される. Cr, Mo の測定 結果は, 主として溶質原子状態での粒界偏析量の変化と 考えられるが，一部は炭化物等の粒界析出も含まれてい る筈であり, 保持時間の增加とともに析出量の変化も想 定される.

脆化後の粒界破面を拡大観察すると, Fig. 12 (a) に示 すごとく大小の粒子が粒界面上に存在することがわか る. 更に Fig. 12 (b) は光学顕微鏡による組織観察試片を 拡大してみたものであるが，粒内にみられる粒子とは別 に，明らかに旧オーステナイト粒界上に連なる粒子が観 察される。 そこで，乙れ等粒子 (析出物) の存在が粒界 偏析挙動におよぽす影響を検討するため, オージェ電子

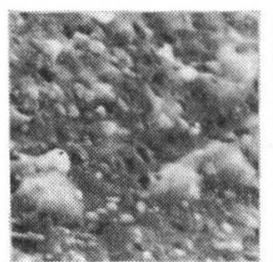

a)

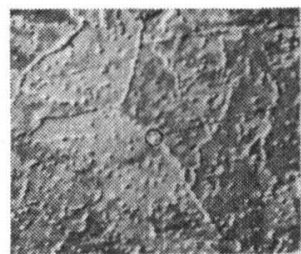

b)
$3 \mu$
Fig. 12 Precipitates at prior austenite grain boundaries a) scanning electron micrograph b) optical micrograph 
分析のビームを $0.3 \mu$ 前後に絞って測定した。

Fig. 13 亿，粒界破面上にみら机る析出物表面 $(\theta-\gamma$ 界面）之析出物のない粒界表面（ $\gamma-\gamma$ 界面）について 测定した結果を整理して示す，P， Cr，Mo とも $\gamma-\gamma$ 界面比跤し， 0 - $r$ 界面作析富化がみられ，脆化処 理時間の增加に伴ない, 雨者の偏析量の違いはさらに強 部されているととがわかる。すなかち，破面上で粒界析 出物の存在する部分は，そうでない部分に比較すると， Cr，Mo を伴ないながら $\mathrm{P}$ 等の笵化不純物元菜がより多 く集稓し，粒界析出物之粒界之の界面（ $\theta-\gamma$ 界面）に 部分偏析を形成すると考えられる。ささらに言えば，粒界 析出物の存在する部分には C あ富化しており，粒界析出 物は Cr および Mo の単独または複合炭化物と推定さ れる。したがって, 逆に, 粒界析出物 (炭化物) を制御 すれば（例元ば粒界析出物の減少），脆化元素の平均粒 界偏析洪度は減少し，脃化を抑制するととも可能である と推定される2).

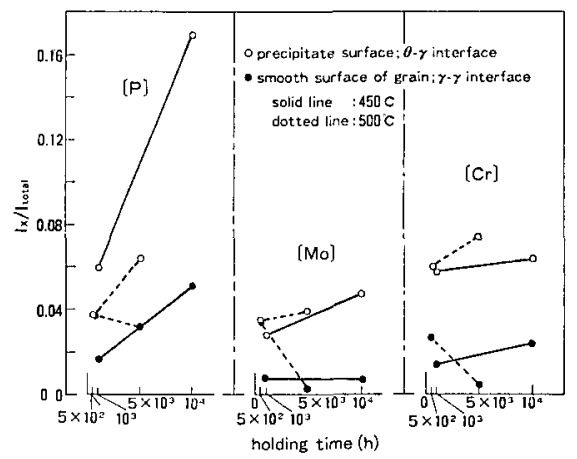

Fig. 13 Summary of micro-Auger spectrum analysis at particular location of fractured surface after a few isothermal treatment

な㧍，こてで対家にしている供試陚片では，脆化処理 前推察できる脆性破面様式は，すべて粒内貴通破面で あり，粒界破面は通常観察されない，したがって，一般 的な方法では，脆化処理前の段階で，粒界によ゙の程度各 元素が存在しているのかを測定するてとができず，偏析 挙動の原点を明らかにするてとができない．との点を解 決するため, 水素脆化現象を利用し, 脆化処理前 (Q. T $+\mathrm{SR})$ の試片を $0.1 \mathrm{~N}$ 苛性ソーダ水溶波中で, $300 \mathrm{~mA}$ $48 \mathrm{~h}$ の電解チャージにより水素添加を行ない, 粒界破面 を現出させた。

Fig. 14 亿同一試料について脆化処理前之脆化処理 後 の粒界偏析量变化の測定結果を示す. 各成分之屯脆化処 理前の熱処理により，すでに若干の㻞析を呈しており， それが绝化処理によってさらに偏析富化されているとと がわかる。

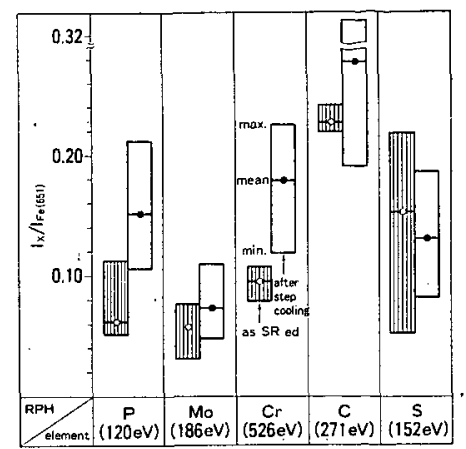

Fig. 14 Intergranular segregation of each element before and after step cooling

ここで注目されることは，脆化処理前および脆化処理 後のいずれにおいても，ばらつきは大きいが，かなりの 量の S の存在が認められることである。しかしながら， $\mathrm{P}, \mathrm{Cr}, \mathrm{Mo}$ といった元素に此校すると, 脆化処理前後に おけるS の量的変化はみられないので, 使用中脆化に刘 しS の影響はないと考えられる。一般に，オージェ電子 分析で $\mathrm{S}$ のピークが認められるととは溶接金属特有の琴 象であることを考えると，溶接金属ではすでに腹化処理 前に S の粒界偏析が形成されており，粒界の破壊䩓性值 を下げていると言える.すなわち溶接金属が母材 (鋼板) に此較して䩓性が低く，策用的な意味で使用中脆化に刘 する評恣度が小さいのはこの点が大きな要因ではないか と桨えられる。

\section{4. 結論}

$21 / 4 \mathrm{Cr}-1 \mathrm{Mo}$ 銓エレクトロスラグ溶接金属の使用中脃 化に関し，肪化要因および粒界偏析挙動の検討を行なっ た結果, 以下に示す結論を得た。

(1) 各成分元䋕の影響について，主要成分战上び微量 元菜の使用中腕化に対する寄与を明らかにした.

a）使用中脆化汶対する主要因は，P の粒界编析にあ る.

b) $\mathrm{Si}, \mathrm{Mn}$ は，P の粒界偏析を助長するといった間 接的な䣸きのほか，Mn はそれ自身粒界偏析することに よって㨁接脆化に駦与している. いずれにしても， $\mathrm{Si}$, Mnの含有量を低くするてとが望ましい.

c）粒界に析出した炭化物は，直接又は間接的に胞化 の一因として作用している。

d） $2 \frac{1}{4} \mathrm{Cr}-1 \mathrm{Mo}$ 系に比へ, $3 \mathrm{Cr}-1 \mathrm{Mo}$ 系は㴔化感受 性が著しく大きくなる。一方， $1 \frac{1}{4} \mathrm{Cr}-1 \mathrm{Mo}$ 系は脆化感 受性が低い.

e） $\mathrm{Cu}$ の源加は脆化感受性を増大させる

f）強度確保を目的として微量添加される $\mathrm{V}, \mathrm{Nb}, \mathrm{Ti}$ 
のうち $\mathrm{Nb}, \mathrm{Ti}$ は，蜮性低下のため笑用的に不可であ

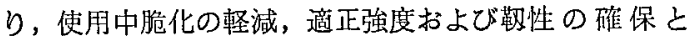
いった観点から V 添加が最もすぐれている。

（2）基本成分系の溶接金属について等脆化曲線を求 め，粒界偏析誉動との関係を検討し以下の知見を得た。

a） $2 \frac{1}{4} \mathrm{Cr}-1 \mathrm{Mo}$ 鋼エレクトロスラグ溶接金属の等脆 化曲線は， nose のある $\mathrm{C}$ 曲線を示し，その北状は，Ni $\mathrm{Cr}$ 鋼 (Jaffe) と $\mathrm{Cr}$ 銅 (Vidal) の場合の中間的北状 を呈する。

b) Step cooling による結果上定温長時間脆化処理に よる結果との比較で，両者の相関は成分系，熱処理履歴 等で大巾に異なる。

c） $\mathrm{P}$ をはじめ各成分とす，保持時間の增加ととあに 偏析量が増え，ある飽和量に達する傾向がみられる，上 くに, P 编析量の経洔变化は， C, Cr, Mo といった析 出物形成元素に比べて大きい.

d）各成分の粒界偏析は，脃化が進行するよりも早く 飽和量に達している。

e）粒界微小析出物は Cr および Mo の単独もしく は複合炭化物と推定され，乙れが偏析サイトとして憉い て P がその近傍に選択的に偏析する。

f）使用中脆化に対し，S の筩与はみられないが，溶
接金属では脆化処理前にかなりの量の S の粒界偏析が形 成されている。乙れが粒界破壊形態をとった場合の溶接 金属勱性が母材に此へて低い一因之推定される。

\section{参 考 文 献}

1) M. Okumura et al. ; "Electroslag Welding of Heavy $21 / 4 C_{r-1 M o}$ steel", Wdg. Jnl. Res. Suppl., Vol: 55 (1976) No. $12, \quad 389 \mathrm{~s} \sim 399 \mathrm{~s}$

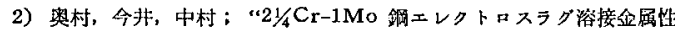
能に特よばすバナジムの喝㸷”（本誌投稿中）

3）中村，策田，渡辺；“Cr-Mo銅中の粒界僻析とそれによる脆化”， 鉄と鍓，第65年 (1979)，第13奇，102 111

4) J. Kameda, C.J. McMahon, Jr. ; "Solute Segregation and Brittle Fracture in an Alloy Steel", Met. Trans. Vol. 11A (1980), January, 91 101

5) R. Bruscato; "Temper Embrittlement and Creep Embrittlement of $2 \frac{1}{4} \mathrm{Cr}-1$ Mo Schielded Metal Arc Weld Deposits", Wdg. Jn1. Res. Suppl., Vol. 49 (1970) No. 4, 148s 156s

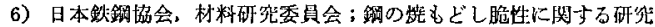

7) H. Ohtani et al., ; "New Information on the Mechanism of Temper Embritlement of Alloy Steels", Metallurgical Transactions Vol. 5A (1974), February, 516 $\sim 518$

8) L. D. Jaffe et al. ; "Isothermal Temper Embrittlement", Trans. ASM, Vol. 42 (1950), 604 618

9) G. Vidal ; "Sur la fragilité de revenu des aciers au chrome, au Molybdène, au Tungstène', Rev. de. Me. tallurgie 42 (1945), 149 155

\title{
再熱割れにおよぼす V 及び Ti の影響*
}

$-\mathrm{Cr}-\mathrm{Mo}$ 鋼の再熱制れに関する研究（第 4 報）-

互 置 維 昭**，鈴 木 实 平**

\begin{abstract}
Influence of $\mathrm{V}$ and $\mathrm{Ti}$ on the Reheat Cracking*
-The Study of Reheat Cracking of Cr-Mo Steels (Report 4)-
\end{abstract}

by Koreaki Tamaki** and Jippei Suzuki**

Influences of $\mathrm{V}$ and $\mathrm{Ti}$ on the reheat cracking sensitivity of Cr-Mo steels were investigated using 13 synthetic $0.06 \%$ V-bearing and 9 synthetic $0.07 \%$ Ti-bearing Cr-Mo steels, which contained 0 to $2 \% \mathrm{Cr}$ and 0.25 to $0.8 \%$ Mo. Cracking sensitivity was evaluated in term of the critical restraint stress; $\sigma_{\mathrm{AW}}$-crit obtained by the implnat type reheat cracking test. The results are summarized as follows. (1) $0.06 \% \mathrm{~V}$ addition increases the cracking sensitivity especially in the content region of low Mo. (2) $0.07 \% \mathrm{Ti}$ addition increases the cracking sensitivity especially in the content region of low $\mathrm{Cr}$ and high Mo. (3) Two important factors which dominate the critical rsetraint stress are the stress relaxation; $\mathrm{R}$ and the grain 